\title{
Is Islam Pro- or Anti-Environmental? Interpretations and
}

\section{Implications}

\author{
Peyman Hekmatpour ${ }^{1}$, Thomas J Burns ${ }^{1 *}$ \& Tom W Boyd ${ }^{1}$ \\ ${ }^{1}$ Department of Sociology, University of Oklahoma, USA \\ *Thomas J. Burns, E-mail: tburns@ou.edu
}

\begin{abstract}
Religion has, throughout the centuries, been a powerful institution on the macro level, yet also stands as a force having significant influence in people's personal lives. This does, however, lead to questions of how a traditional institution such as religion may or may not be adequate to address problems of the Late Industrial Era, most notably the environmental crisis. In this paper, we inquire how various dimensions of Islamic literature and thought can contribute to preserving the natural environment. We find that concepts such as "dominion of men over the earth" and "specialness of humankind" can lead to anti-environmental interpretations of Islam. Nevertheless, other interpretations of Islamic teachings emerge that are compatible with environmental stewardship. However, a number of Islamic governments have shown a decided bias against environmental stewardship, particularly in cases where there is an authoritarian government and one placing an emphasis on economic "development". In counterpoint, Islamic Mysticism, or Sufism, can provide a spiritual context for environmentally conscious action.
\end{abstract}

\section{Keywords}

Islam, environmental crisis, Qur'anic studies, Hermeneutics, Sufism, Environmental Sociology, Sociology of Religion

Throughout history, religions have had an influence on society and cultures, and this has continued to the present day. Yet a strong case can be made that the global and life-threatening environmental problems facing humanity now are greater in magnitude and scope than they have ever been before in the history of humankind (Burns \& Caniglia, 2017; Ponting, 2008; McNeill, 2000).

\section{Introduction}

Some might say that what humanity faces is nothing new, that our current environmental situation is what it has always been, that the planet and its inhabitants are a durable presence that have lasted through the ages and will continue to do so regardless of the current concerns. McNeill (2000), reconsiders this view through a different lens, making the case that environmental problems of the Third Millennium do demonstrate that there is "Something New Under the Sun". The very title of McNeill's book is a play-on-words from the scripture in the Tanakh (book of Ecclesiastes) that states, "there is nothing new 
under the sun.” The notion that what is currently being faced is not new is challenged by McNeill and others; levels of environmental pollution, deforestation, global climate change and destruction of habitats have reached crisis levels in many cases (Burns \& Caniglia, 2017). The concern has become so great that this age of crisis has been deemed by some the Anthropocene Age, characterized by humankind's profound influence on the ecology of the planet (Crutzen, 2002).

Religions around the world have long held beliefs and practices that were rooted in their cultures and societies from long before the Industrial Era. In studying environmental consciousness and how religion plays a part in its shaping, both past and present interpretations are a product not only of the ages and cultures in which they were written, but of who reads them and how they are interpreted over time.

In this paper, we focus on the Islamic tradition and its rich textual history, looking primarily, though not exclusively, to the Qur'an itself. This in turn can offer a view as to how people in this tradition tend to conceptualize, and ultimately relate to, the natural environment.

\section{Religion and the Industrial Age}

As we search for clarity about this world and its environmental challenges, it bears noting that it is not uncommon for religions to offer a dominant (and in some cases the dominant) viewpoint for a culture (Burns \& LeMoyne, 2003). Individuals, including those with other than spiritual motives, will often use those religious ideas as a backdrop in which to package their own views, in hopes of making them seem "reasonable" (Royal, 1999). As with many or most problems throughout time, society can find something in their religious doctrine, and in the tradition more generally, to back their claims. Of fundamental concern here, is how religious beliefs and background influence how people think about, and react toward, the natural environment.

Yet the stark awareness of many of the environmental problems of the world came into focus only in the more recent years of the Late Industrial Era. Religious texts do not directly address industrial problems. This is not to say that these older canonical texts do not apply at all to those problems, and a case can be made that they apply in a myriad of ways. Yet those applications require some careful consideration. To which problems, and to what aspects of those problems do spiritual texts, or a set of passages in them, apply? Attempts to adapt religious writings are always subject to a variety of cultural and rhetorical considerations (Burns, 1999, 2012). Every text has a context, and the geography and history of the people producing it are huge considerations. Yet this fact can be lost in the attempt to "universalize” spirituality (Burns, 2016).

Recently, a group of scholars, including John Cobb $(1995,1999)$ (also see Bube, 1988; Daly \& Cobb, 1994), Robert Fowler (1995) and Matthew Fox (1988), have attempted to explore many of the rich connections between the environment and scripture. In fact, virtually every tradition has much to say and the messages are sometimes simple, sometimes complex, and often contradictory (Burns, 2014). Scholars throughout the ages have added their interpretations, though often to rationalize some action which may be markedly different from someone else putatively taking counsel from precisely the same text. 
While there is a large and growing literature on religion and the environment, the preponderance of work has been published in the West, and has been particular to Christianity. This, however, is changing slowly, as more scholars invest in studying the outlooks and mindsets of peoples in cultures from around the world and their level of consciousness toward the environment. Important questions remain as to how people informed by scripture will think about, and act toward, the natural environment. After a brief excursus on method, let us consider some of the formative influences on the Abrahamic Traditions, and then turn to Islam in particular.

\section{Notes on Method}

We look to canonical texts in Islam, Primarily the Qur'an, for a sense of how Muslims are likely to view the environment. We take guidance from Max Weber, particularly his work on comparative religions, and also from his Methodology of the Social Sciences (1903-1917/1949). His approach could be characterized, broadly speaking, as hermeneutical, as can ours. Like Weber, we attempt to be guided by the vision of Verstehen, or coming to an underlying understanding of our subject, rather than collecting and "number crunching" some quantitative data. Our study is based in the belief that delving into the texts is one of the best ways to gain this sort of understanding.

There are several caveats that bear mentioning here early in the paper. In this paper, we read and interpret texts, as best we can, through the lenses of the social sciences, and not as practitioners or apologists. We may refer in passing, for example to the divine provenance of a text; in so doing, we are not attempting to take a position on its divinity. Rather, the point is to convey, as best we can, what we see as a commonly held belief by a social collective-in this case, a group of Muslims reading one of their central texts.

It is important to treat any translation with caution. The Qur'an was written in Arabic, and some Muslims believe that reading the Qur'an in another language loses a major aspect of the experience. The reasoning goes that since Allah revealed the teaching in Arabic, any language other than that may not give the full experience of the original. In this view, a translation—any translation, albeit one done in good faith—can be thought of more as a text about the Qur'an, than the Qur'an itself.

Our approach is to try to move beyond essentializing the texts. Rather, we look for competing "dialogic" (Bakhtin, 1981) strains, or varying ways in which texts can and have been interpreted. This is very much in the spirit of hermeneutic analysis more generally (Gadamer, 1976).

It is important to read texts, not just passively, but in an active, connective way. Each phase of history places its own constraints and demands on a text, and encourages people to read it in a way that might have been unpopular, or even unthinkable, in a prior era or a different place (Ricoeur \& Blaney, 1990; Andrews, 2007).

Our approach, then, is to read primary canonical texts, interrogating them for meaning about how humankind is to interact with the natural environment. Throughout, it will be important to keep in mind that the ways in which people in communities interpret the texts will be constrained and influenced by outside factors, such as history, geography, demography, politics and culture (Ricoeur, 1976). This does 
not diminish the importance of the texts, but rather, it reminds us to be aware of how such influences can and do have significant impacts.

\subsection{The Abrahamic Traditions}

Because of the sheer numbers of people confessing some aspect of the Abrahamic faiths (Christianity accounts for about a third of the over seven billion people on the planet; when adding Jews and Muslims to the mix, the proportion rises to over half of the total world population). Combined with the often —not always, but often enough to make a difference-intertwining of religion with the political and cultural powers of the day, these religious traditions bear particular scrutiny for their influences on people and societies.

Yet they have humble origins, arising from among desert peoples. The trials and tribulations are embedded in circumstances faced by those people at a time long ago (Turner, 2017). Even if, as is often the case, the vision is other worldly, that other world is rich in images of the natural world as it existed, or as it was imagined, in times long past (Eisenberg, 1998).

We see in the Jewish and Christian traditions (which in turn heavily influenced Islam), an origin story with plenitude. Most notable perhaps is the account from the Torah (in the book of Genesis) of the Garden of Eden. In this narrative, God provides as much and more as humankind would need, but man and woman are, in return, to obey God.

As Genesis unfolds, however, the story has early humankind, represented by Adam and Eve, not following God's direction. They were, in punishment, expelled from the Garden of Eden. Thus, very early on, there is an Edenic vision of plenitude, juxtaposed with humankind's sinfulness and loss (Eisenberg, 1998).

Much in Christianity and Islam extend back to their ties with Judaism. Of interest in this regard is something going back to a singular event in the Book of Genesis-God's covenant with Abraham. God promises Abraham that his descendants will be as numerous as the stars, and to be fruitful and multiply. The sheer sizes of Christianity and Islam are at least partially due to their high fertility rates. Perhaps taking God's covenant with Abraham seriously, particularly the part about God's promise to make the descendants of Abraham as "numerous as the stars", birth rates among Christians (and even more so among Muslims, but not among Jews) are far above replacement levels, and significantly higher than among most other religious traditions (Jenkins, 2011).

This needs to be qualified, however. When controlling for other variables, most notably modernization of the country in question (measured independently of religion), levels of education (particularly women's education), and urbanization, these "trends" become less obviously a function of religion, and more attributable to these other factors (Inglehart \& Baker, 2000; Dyson, 2010).

Judaism and Christianity are, of course, different religions. Yet passages from the Hebrew Tanakh stand as foundational to both. The first three chapters of the first book of the Torah, the book of Genesis, are central to both traditions. Perhaps the passage that is most studied, debated, quoted (and taken out of context, if not outright misquoted) is Genesis 1: 26-28.

Published by SCHOLINK INC. 
This is the verse that says that Humankind (or "Man", in many versions, particularly those translated before well into the Industrial Era) is to have "dominion" (or in some renderings, "stewardship") over the earth and its creatures. The specifics of how to envision dominion have been a matter of much thought and consideration by believers since then, as they draw on this passage and other scriptures to inform and guide their actions. A seminal article by Lynn White (1967) constructs this passage as foundational in Christianity's difficult relationship with the natural environment, but stops short of exploring implications for the other Abrahamic traditions (Jobling, 1977).

The third chapter of Genesis tells of the "fall" of humankind in partaking of the forbidden fruit of the tree of knowledge. Genesis 3: 23 tells how God's wrath affects Adam and Eve as the first humans, when they are cast out of the Garden of Eden. They, and all their descendants, are to till the fields for a living after the expulsion.

The desert and shepherding images come up repeatedly in Judaism and Christianity (Hareuveni, 1991). These themes are found in Islam as well (for discussion, see Johnston, 2010). Jesus is the good shepherd; in the end, the sheep (those bound for Heaven) will be separated from the goats (those going to Hell). As Moses and the Jewish People wander in the desert in the book of Exodus, so Jesus, just prior to entering his public ministry, goes into the desert to fast and pray, and to otherwise prepare himself to reenter to public realm for his life's mission. Like Moses and Jesus, Muhammad's views, as well as those of his followers particularly at the time of the writing of the Qur'an and the Hadiths, could not help but be affected by his natural geography. This very much included experiences of the desert (Johnston, 2010). The purport of this becomes increasingly significant over time, as the Abrahamic religions go from being particular to the desert, to spreading more broadly, ultimately to becoming the predominant world religions. It is no exaggeration to say that Islam probably grew more quickly, particularly in its early years, than did any religion before or since. To give a sense of scope, within a century of Muhammad's death in 632 C.E., Islam had spread as far East as Central Asia, and as far West as Western Europe.

As quickly as the religious institution may expand, the metaphors and other tropes still are grounded in the particular. They adapt only slowly as the religion strives for universality. In the process, there is significant cultural lag (Ogburn, 1932/1961; Burns, 2009). Many of the problems of the environment, particularly those associated with advanced technology and other artifacts of Late Modernity, are addressed only tangentially by the older tropes (Lakoff \& Johnson, 1980).

\subsection{Islam and the Environment}

There have been many debates on how religion, as a social institution, can have effects on one of the most important social problems of our era, the environmental crisis. Most of these debates, as reflected in the literature thus far, have been concerned primarily with Christianity (Cobb, 1995, 1999; Bube, 1998; Burns, 2014). However, in this time that people are increasingly becoming more interconnected, and the environmental crisis becomes ever more pressing, it is of the utmost importance to know about different religious traditions, and how they can have negative or positive contributions to the environment.

Published by SCHOLINK INC. 
Max Weber (1904-5/2002) theorized about how religious beliefs and ethics (particularly those of Protestantism) can contribute to the formation of capitalism. Lynn White (1967) made a case that certain interpretations of Christian scriptures can create a context for the emergence of environmental problems in the West. However, he also allowed for other possible interpretations, which could be compatible with environmental stewardship (White, 1967). More recent work by Burns (2014) has made the case that many of the major world religions (particularly, but by no means solely, Christianity), can be interpreted across a wide array of environmental attitudes, from environmental protection to profligacy.

Islam is the world's second largest religion, in term of the number of adherents, after Christianity. Today there are 1.4 to 1.8 billion Muslims living around the world, constituting over one-fifth of the world's population (Saniotis, 2012). Most of these people are living in developing or underdeveloped countries, ofttimes struggling to attain the comforts of living, many of which are already taken for granted by consumers in Western developed countries. In the struggle, there is often the tendency to discount environmental costs (Schnaiberg \& Gould, 2000). As Muslims are trying to achieve “development”, it is important to know how Islam can deal with environmental issues.

Although there is much less literature on this topic than in the Christian tradition, what there is suggests at least a significant aspect of an Islamic ethos which is completely compatible with the environment. In this view, environmental problems that we do see in Islamic countries are primarily attributable to political issues (Kula, 2001; Rice, 2006; Rizk, 2014). Nevertheless, in this paper, we find evidence that Islam could be interpreted as both pro and anti-environment.

Islam, like Christianity and Judaism, does have the potential to be interpreted in an anti-environmental way. We find in particular, two core concepts within the Abrahamic religions, which could make them less than nurturing to the natural environment: humankind's dominion over the earth, and specialness of humankind. We then will examine how Islam is considered and interpreted, mostly by Muslim environmentalists, as completely compatible with the environment. Next, we will discuss Islam in action, regarding the environmental crisis, particularly in terms of how Muslim people and governments tend to act toward the natural environment. Finally, we will bring up the small but significant current of Islamic mysticism, or Sufism. We explore it as an alternative approach having the potential to help address environmental problems in significant ways, not only in the Islamic countries, but also around the world.

\subsubsection{Islam: The Last in the Abrahamic Religious Sequence}

Islam, like Christianity, is highly influenced by Judaism. All three share a somewhat similar myth about the beginning of creation-for instance, the creation of the world and all things in it in six days (Genesis 1: 31; Qur'an 7: 54) and the story of the Garden of Eden and how Adam and Eve were expelled from it for eating the fruit of the forbidden tree (Genesis 2; Qur'an 7: 19-24) are nearly identical. In a related vein, an important concept within the Abrahamic religions that has redounded in environmental problems ever since, is the belief in dominion of humankind (or of men, depending upon 
the interpretation) over the earth and everything in it.

Although this dominion is actually declared in the Torah (Genesis 1: 26-28), it is merely implied in the Qur'an (Idris, 1990; Chitlick, 1986; Wersal, 1995). In the following passages, we will elaborate on some Qur'anic verses from which the concept of dominion has typically been interpreted.

In an Islamic context, when Adam and Eve were expelled from the heavens, they were settled on the earth. The earth and everything in it is subjected to them, for their enjoyment and benefit:

And for you on the earth is a place of settlement and enjoyment for a time (Qur'an 7: 24).

But this settlement is just "for a time" because all people will come back to their Creator on the Day of Judgment and will be sent to either Heaven or Hell, depending on what they have done on the earth (Qur'an 29: 57, 74: 38 and 2: 81-82). In addition, it is the destiny of the earth to be destroyed before the Day of Judgment:

[T] here is, at its occurrence, no denial. It will bring down [some] and raise up [others]. When the earth is shaken with convulsion and the mountains are broken down, crumbling and become dust dispersing (Qur'an 56: 1-6).

Therefore, the earth is just a temporary habitat for humankind, and no one knows the exact hour of its destruction, but the God himself (Qur'an 31: 34). However, while people are living on it, they can enjoy from it (Turner, 2017). This issue is declared in several verses.

And He has subjected to you whatever is in the heavens and whatever is on the earth-all from Him. Indeed, in that, are signs for a people who give thought (Qur'an 45: 13).

God subjected whatever is in the heavens and on the earth to men. Therefore, they can use it as a gift from their god. Alongside the heavens and the earth, he also provided men with seas, to be used as a food resource and for transportation.

And it is He, who subjected the sea for you to eat from it tender meat and to extract from it ornaments which you wear. And you see the ships plowing through it, and [He subjected it] that you may seek of His bounty; and perhaps you will be grateful (Qur'an 16: 14).

He also provided men with water from the sky, which could be used for their drinking, growing different plants, and pasturing their cattle.

He, it is Who sends down water for you from the sky out of which you drink and out of which grow the plants on which you pasture your cattle and by virtue of which He causes crops and olives and date-palms and grapes and all kinds of fruit to grow for you. Surely in this, there is a great Sign for those who reflect (Qur'an 16: 10-11).

These verses and other similar verses could be interpreted as signs of the dominion of humankind over the natural environment. In addition, it could lead to the idea that God provides, because he says he does, regardless of what humans do on the earth. He only wants people to think and take the natural environment as a sign of his existence. He is both almighty and merciful, who sends the rain and grows the plants so people do not have to be worried about the environment, because it is all in God's hands to manage.

Published by SCHOLINK INC. 
In the book of Exodus (chapter 16), the people are the beneficiaries of God's largesse in a number of ways, not the least of which is in the form of Manna from Heaven. This too is an important story in Islam (see the Qur'an, Surah 2, verses $57 \mathrm{ff}$.):

And we shaded you with clouds and sent down to you manna and quails, [saying], "Eat from the good things with which we have provided you (Qur'an 2: 57).

This is a story of special intervention, even in the face of an environment that is incapable of sustaining people in a natural manner. The Deus ex machina belief that God will provide, even if the environment has not been stewarded sufficiently to keep it in a state of fecundity, thus appears to be available in Islam, as well as in the other Abrahamic traditions.

The other mutual concept of Abrahamic religions, which could lead to environmental problems, is the "specialness of humankind" originally coming from Judaism, and found in Christianity (White, 1967; Burns, 2014). This is the idea that humankind has some sort of superiority over the natural environment. This concept can be found in verses of the Qur'an as well.

And we have certainly honored the children of Adam and carried them on the land and sea and provided for them of the good things and preferred them over much of what we have created, with [definite] preference (Qur'an 17: 70).

The case is made that god has preferred humankind to much of what he has created and he has chosen it to be his successor or Caliph on the earth. Further, legitimation for inequality within humanity can be found in these verses:

And it is He who has made you successors upon the earth and has raised some of you above others in degrees [of rank] that He may try you through what He has given you. Indeed, your Lord is swift in penalty; but indeed, He is Forgiving and Merciful (Qur'an 6: 165).

Humankind is, at the most perfected form, and earth and sky are made to be its place of settlement and ceiling. The goal of the natural environment is to serve these benefactors of Allah, the Lord of the world.

It is Allah who made for you the earth a place of settlement and the sky a ceiling and formed you and perfected your forms and provided you with good things. That is Allah, your Lord; then blessed is Allah, Lord of the worlds (Qur'an 40: 64).

Putting all these verses together, one can conclude that Islam has the very potential to be interpreted in an anti-environmental way, as does Christianity and Judaism. Islam thus shows some striking parallels with the one or both of the other Abrahamic religions in a number of ways. The purport is that humankind is enjoying some level of dominion over the earth, mainly because of its special position in God's creation.

In the Muslim variant, Men are regarded as the "Viceregent" of Allah on earth, and Allah himself has provided such a position (Idris, 1990). On the other hand, Allah assures his followers that everything is in his absolute power. They will not have to be concerned about what is happening to the environment as surrogates of God, having superiority to other creatures and having dominion over the earth and seas Published by SCHOLINK INC. 
while God has ensured them that he provides them with everything needed, just as he has done in the past. This interpretation has been seen among both Muslim modernists and Muslim fundamentalists (Nasr, 2009).

However, this is not the only possible interpretation of Qur'anic verses regarding the natural environment. In the next section, we will show how Islamic teachings and thoughts can be, and have been, interpreted in a more environmentally friendly manner.

\subsubsection{Pro-Environmental Islam: One Possible Interpretation}

Alongside the verses outlined in the last section, which could justify or perhaps even lead to anti-environmental behaviors, there are many verses in the Qur'an, warning people not to abuse the environment. In Islam, only those who remain God's servants, acting exactly as he wants, can enjoy their dominion upon earth and be God's successor. They should act like God himself, who dominates all things, but at the same time cares for them (Nasr, 2009). Therefore, as God's successor, humankind should take care of the earth.

And cause not corruption upon the earth after its reformation. And invoke Him in fear and aspiration. Indeed, the mercy of Allah is near to the doers of good (Qur'an 7: 56).

Corruption upon the earth is regarded by Allah as a disagreeable act. It also can show people's ingratitude to their creator and his creation, which is complete and flawless (Qur'an 67: 3). If there are corruptions on the earth, it is humankind's fault, for which it will face the consequences.

Corruption has appeared throughout the land and sea by [reason of] what the hands of people have earned so He may let them taste part of [the consequence of] what they have done that perhaps they will return [to righteousness] (Qur'an 30: 41).

The other thing, which is indecent to Allah's kindness toward humankind, is the exploitation of the earth. As God's Caliph(s), people are allowed to consume what has been provided only as much as is needed, and no more. Overuse will lead to corruption.

O children of Adam, take your adornment at every masjid, and eat and drink, but be not excessive. Indeed, He likes not those who commit excess. (Qur'an 7: 31) Eat and drink from the provision of Allah, and do not commit abuse on the earth, spreading corruption (Qur'an 2: 60).

Therefore, we can say that in Islam the dominion of humankind over the earth is more like being the steward of it, rather than its master (Khalid, 1996). Many scholars have used these and other verses from Qur'an in addition to some Hadith verses, quotations from Muhammad's notebooks, to claim that Islam is a completely environmentally friendly way of life (Saniotis, 2012).

Some Muslim thinkers and theologians, interpreting the Qur'an and Hadiths, believe that Islam should be compatible with the environment. They refer to Islam as the religion which is compatible to the instinctive and primordial nature of humankind. In their opinion, there should be a permanent relationship among humans, nature and God. In this interpretation, environmental problems are due to the alienation of humankind from nature and God (Chishti, 2007).

Scholars of Islamic Ethics also have something to say about environmental problems. In Islam, being Published by SCHOLINK INC. 
kind to the natural environment is considered a great moral virtue, as important as modesty and justice. Hence, as God wants people to have a virtuous life, they should act as stewards to the environment (Cragg, 1971). Disrupting the natural order and balance is not only considered unethical in Islam, but also sinful and worthy of punishment (Kula, 2001).

The history of Islam, especially in its early stages, also can show its emphasis on the natural environment (Saniotis, 2012). This emphasis was particularly the case with water, the most precious resource for people in the desert (Ahmad, 1999). Muslims of the early years developed sophisticated water usage laws and some technologies for its distribution and maintenance in the most efficient way possible (Wilkinson, 1990).

Another instance of environmentally friendly attempts during the history of Islam is the establishment of Hima territories, reserved areas protected from aimless harvesting or hunting. Hima existed before Islam among the people of the Arabian Peninsula, but they were private reserved areas that belonged to the most powerful headmen. With Islam, its function changed to be used for the well-being of the community. Hima areas could not be traded as a commodity, nor could they be cultivated or built upon for financial purposes (Gari, 2006).

Hima areas could be established anywhere in Islamic territory if they met certain conditions, based on the practices of the Prophet Muhammad and of the Rashidun Caliphs (these were the very first Caliphs, said to be "Rightly Guided" by Allah, whose reign occurred before the Sunni/Shi'i split).

First and foremost, Hima areas were to be established by the legitimate Islamic state or the Caliphate. Second, the purposes behind the establishment of a Hima had to contribute to the welfare of the Islamic community. Third, the Hima area should not be so large as to cause hardship to local residents, depriving them of resources (Haq, 2001).

In Hima areas, grazing was forbidden for a specified period during the year. This period started in winter and continued to the warmer seasons of the year in order to provide enough time for grasses and trees to grow and reproduce. There were specified Himas for bee keeping where grazing was allowed only after the flowering season. Despite its usefulness from an ecological viewpoint, and due largely to the political instability of Islamic countries, this system was largely abandoned. It does, however, still exist among a few tribes in countries such as Saudi Arabia, Yemen and Syria (Gari, 2006).

As we have seen, pro-environmental interpretations of Islam are possible based on the Qur'an, Islamic theology, ethics, and its history. However, when we look at the now existing situation of Islamic countries and Muslim people, an indifference to environmental problems can be seen among many Muslims, perhaps even the majority. So despite this considerable potential for environmental stewardship, there is evidence that Muslims living in predominantly Islamic, especially Middle Eastern, countries often tend to remain relatively unconcerned about local, national, and international environmental problems (Saniotis, 2012; Nasr, 2009). In the next section of this paper, we will discuss why. 


\subsubsection{Anti-Environmental Political Islam}

Much of what today is called the Islamic World, was colonized by Western European powers during the past centuries. Some Islamic scholars (e.g. Nasr, 1997) make the case that colonization of Muslim countries had a negative impact on the state of Islamic ecological and environmental practices. This view holds that Western powers diminished Islamic ecological practices by imposing their understanding of the environment, which was highly influenced by their own perception of Christianity that in some interpretations views the environment in utilitarian terms (Nasr, 1997) (although it bears noting that Muslim imperial powers tended not to have strong environmental records either).

The validity of these claims is beyond the purview of this paper, but could be investigated in other research. However, the one obvious point is that colonization has had huge negative social, economic, and environmental impacts on colonized regions (Burns \& Rudel, 2015), among which are many Muslim majority countries (Nasr, 1997). That is because the first goal of colonization was to transfer the wealth of colonized countries to the colonial powers (Moore, 2000; Foster, Clark \& York, 2011). Now that the colonial era has passed or has given way to neo-colonialism, many of the former colonized countries have remained underdeveloped, trying to reach levels of Western developed countries in term of wealth and power (Barber, 1995; Schnaiberg \& Gould, 2000).

Development has become the primary goal of a number Islamic countries. They argue that they have a right to be developed (Williams, 2005) but to do so, they need the help of the former colonial and now developed Western nations. Islamic governments have largely accepted modern Western science and technology (Nasr, 2009). The foundation for implementing Western technologies is to have enough energy, and this has caused Islamic countries to build the infrastructure of their economies on fossil fuels, which means inevitable increases in greenhouse gas emissions and other sorts of environmental problems. The primary aspect of development Islamic countries are seeking tends to focus on economic development to the detriment of other types of cultural and social development. This, in turn, tends to diminish consideration for environmental issues (Saniotis, 2012).

One of the most important problems across many Islamic countries now is over-population. The rapidly growing human population can lead to environmental degradation and exhausted ecological resources (Kula, 2001; Sanities, 2012). This phrase is widely attributed to the Prophet Muhammad:

Marry and reproduce, so I would be proud of you on the Day of Judgment (Wasā'il al-Shī' a, 20: 14).

According to Harrison (1993) a popular reading of this Hadith verse, as well as one favored by a number of Muslim writers, supports the idea that family planning is a strategy employed by adversaries of Islam in Western countries, to discourage Muslims from growing and from taking leadership as they are promised by Allah in the Qur'an:

And we want to confer favor upon those who were oppressed in the land and make them leaders and make them inheritors [of the earth] (Qur'an 28: 5).

The governments of many Islamic countries contend that family planning is a way used by Western countries to stop them from growth. This is a central reason birth control is not encouraged in these

Published by SCHOLINK INC. 
Islamic countries (Kula, 2001).

Nevertheless, environmental issues are not absent in political debates in the Islamic World. Some scholars believe that leaders in Political Islam often have a tendency to use environmental issues for blaming their enemy, which frequently can take the form of some figure or institution in the West. The message may be overtly pro-environmental, but the message to their people is that the West is responsible for environmental problems. It is part of a larger ideological and political framework, which is the struggle against Western policies. Islamic governments thus are able to fashion an out, at least temporarily, from their responsibilities for stewarding the natural environment. By blaming the Western secular life style, they have effectively framed a scapegoat (Erdur, 1997; Kula, 2001).

Political Islam thus has a dual strategy regarding Western nations. First, it has a goal to be developed, so there is a warrant for the formation of powerful states. However, the heightened priority on development has overshadowed the latent Islamic sense of environmental and ecological ethics (Saniotis, 2012). On the other hand, the increasing severity of an existing environmental crisis in the Islamic World is undeniable.

The efforts of these governments to achieve economic development regardless of its other costs, have caused the diminishing of an otherwise potentially significant Islamic environmental ethic and practice among the people. Most Muslims have not yet completely realized the potential of Islamic environmental teachings. However, for Muslim environmentalists, another barrier is the totalitarian nature of many, if not most, of the governments in the Islamic World. A number of these regimes are in favor of population growth, which may conceal a less socially sanctioned goal of achieving a cheap labor force which is needed for implementation of the often-vilified Western technological mode of production (Asmal \& Asmal, 2000). Yet while openly criticizing the state's development programs can be dangerous anywhere in the world, this is particularly true in Islamic countries (Nasr, 2009; Rice, 1999).

\subsection{Islamic Mysticism: An Old Way into the Future}

Sufism is the mystical branch of Islam, considered as a spiritual path which can lead those who believe to the divine truth or knowledge (haqiqa). The core idea of Sufism is that there is one and only one truth, which is placed in the hands of God (Chitlick, 2000). To reach that truth, it is not enough to be just a Muslim, following the rules intended to regulate the social life of the Muslim societies. The ultimate truth, haqiqa, is beyond everyday life and to find it, one will need something more than Sharia (or the exoteric rules of everyday life). This higher state, which is Tariqa, is found in the Sufis' orders and rituals (Akman, 2008; Burckhardt, 2006).

The substance of Sufism is the concept of selflessness or "fana" which requires attaining a high level of self discipline. There is the belief that when a Sufi reaches the point of $f a n \bar{a}$, he would at that point be identified as the "Universal Man”, like the Prophet Mohammad himself who emptied his heart of anything else but Allah and reached the status of eternity, or "baqā" (Akman, 2008; Michon \& Gaetani, 2006). 
According to Geoffroy (2006) the dualistical experience of fanā and baqā is essential in Sufism, as Junayd of Baghdad, one of the key figures in Sufism said: "[Truth] is summed up thus: the Real [or, the 'Truth', i.e. God] makes you die to yourself, and causes you to come alive again through Him” (Eissa, 2007). This concept comes from the interpretation of the Qur'anic verse:

Everyone upon the earth will perish, but there will remain the Face of your Lord, Owner of Majesty and Honor (Qur'an 55: 26).

If one does not want to perish, one should join the Face of the Lord. But what is the Face of Allah? The Qur'an addresses this question in another verse:

And to Allah belongs the East and the West. So wherever you [might] turn, there is the Face of Allah. Indeed, Allah is All-Encompassing and Knowing (Qur'an 2: 115).

This has led to one other important concept within Sufism, which is the "unity of existence" or the "oneness of being” (wahdat-al-wojood), first introduced by the most famous Andalusian Sufi of $12^{\text {th }}$ Century, the "Greatest Master" Ibn-Aribi. It means that the individuality of all beings is ultimately going to perish in the being of God, like a drop being lost in the ocean of divine unity (Renard, 2009). In other words, only God alone possesses being. The existence of other things we see on the earth is just because he "endowed them with an existence emanating from his Being" (Geoffroy, 2006).

According to Clarke (2009), this would lead to a perception of the universe as a holistic living order where everything is placed in its perfect position by God and all creatures are completely in God's command. Rumi, one of the famous Sufis of all history, reflects this idea in verses of his book, Masnavi:

All the atoms of earth and heaven are God's army, (as you will find out) on putting it to the test (Masnavi 4: 783). In (all) the earths and heavens not an atom moves a wing, not a straw turns, save by His eternal and effectual command. To expound (this) is impossible, and presumption is not good (Masnavi 3: 1902-3).

It thus could be said that Sufism can provide spiritual impetus for acting in an environmentally friendly way. When one believes that all the things on the earth and in the sky are the Face of God, it would be abhorrent to commit harm to the natural environment. When the first goal of a Sufi is to join with God and to become the Universal Human, he/she should try to be completely compatible with the universal order of the things. This order is sacred, so disturbing it is an unforgivable sin and a disrespect to such a merciful Lord.

As we mentioned above, the cornerstone of Sufism is "selflessness" or " $f a n \bar{a}$ ". Sufis should be ready to sacrifice themselves and their own desires and lusts to the greater creator, whose face is the entire natural environment, from East to West.

\section{Conclusion}

In this paper, we have examined ways in which Islam could help face environmental problems. Islam as an Abrahamic religion shares many roots with Christianity and Judaism. Since an array of Published by SCHOLINK INC. 
interpretations is possible from the Christian and Jewish scriptures, we attempted to find out whether Islamic scriptures have the potential to be interpreted as broadly. Two important concepts, originally coming from the myth of creation, declared in the book of Genesis in the Torah, are considered to have environmental consequences; the dominion of men over the earth and the specialness of humankind. We find these themes in the Qur'an as well, the central canonical scripture of Islam.

The Qur'an does contain verses from which these concepts could be interpreted. Humankind in the Qur'an is considered to have some level of dominion over the earth, sea and even the sky and as God's successor on the earth, can enjoy from its resources. In Islam, humankind has a special position in God's creation and he has preferred humankind over many of his own created things. While these scriptures do have the potential for interpretations in anti-environmental ways, these are far from the only possible ways to frame them.

Alongside verses that declare the dominion and the specialness of humanity, there are many verses also warning humankind not to overuse resources and not to commit corruption on the earth. In these readings it appears that humankind's dominion over the earth is more like stewardship.

On the other hand, Islamic theology and ethics suggest that a pro-environment interpretation of the Qur'an and the Hadith is not just possible, but is more consonant with the nature of Islam. In addition, in the history of Islam there are many examples of how to manage natural resources in order to preserve and protect them from overuse and corruption. One of the good examples of the pro-environment model of managing resources in the history of Islam is Hama, or preserved areas of natural resources intended to be used for the welfare of all the Muslim community.

Despite this potential, major portions of the Islamic World now have chosen another path, mainly due to issues of development. Many Muslim countries were once colonies of Western imperial powers. Now they are impoverished and underdeveloped or developing countries trying to reach to their ideal of "development", based largely on Western technological and economic models. There is an uneasy tension over resentment of the West, and a desire for ever greater levels of consumption and economic growth (Barber, 1995). Governments of these countries take a dual strategy toward the West; it is not uncommon to seek help from Western nations, banks, NGOs, and businesses, and in the meantime, to blame Western institutions or people for environmental problems in the Islamic World. Compounding the problem, these governments are often totalitarian in nature, which makes it difficult and dangerous for a true environmental movement to emerge.

We have tried to show that Islamic mysticism, or Sufism, can help to address environmental problems, by providing spiritual causes and incentives for people to act in environmentally sustaining ways. The core idea of Sufism is that all the earth reveals the diverse faces of God, and the goal of a Sufi should be to join with God. Sufism also emphasizes devotion and selflessness, which are necessary for environmentally friendly acts in this era, in which the culture is so heavily influenced by ideas of disconnected individualism and selfishness.

Finally, we can say that Islam, like other ontological systems of beliefs and ideas, can and does yield 105

Published by SCHOLINK INC. 
different, and at times antithetical, interpretations. It would be a gross oversimplification, and misleading at that, to say that Islamic literature is utterly pro- or anti-environment.

In addition, we do well to keep in mind that world religions are old in a number of senses, not the least of which is that their scriptures were written long before societies faced the crushing environmental crises of the Anthropocene Age. Their tropes are invariably Preindustrial, even as adherents struggle to make meaning in the Late Industrial Era. We cannot necessarily expect them to provide even the most ardent of followers with exact instructions about how to deal with environmental problems.

There typically is a lag between a change in social conditions, and the time it takes for the culture to adapt to it. This “cultural lag” time can be significant (Ogburn, 1932/1961). Because of this cultural lag phenomenon, the responses to problems that have not been embedded in the culture for long periods (McNeill, 2000) may be inadequate because a fully developed moral or ethical system has not yet formed in which to make sense of them (Burns, 2009).

Religiously based literature and rhetoric can be beneficial or harmful to the environment, depending on the moral lenses through which they are interpreted. If global environmental movements are going to find comprehensive solutions for the environmental crisis, they should take the potential of religions in general, as well as many of their particularities, into close consideration (Burns \& LeMoyne, 2001).

Environmentalists all around the world would do well to pay attention to Islam. As we have tried to show in this paper, Islam can be considered, at least in part, responsible for some of the environmental problems in the Islamic World. Yet Islam also holds the basis for an environmentally friendly and life-sustaining culture. Islamic Mysticism, or Sufism in particular, is an age-old tradition that can offer a number of insights for living in harmony with the natural environment, even in the Anthropocene Age.

\section{References}

Ahmad, A. (1999). Islamic Water as an Antidote for Maintaining Water Quality. University of Denver Water Law Review, 2(2), 170-188.

Akman, K. (2008). Sufism, Spirituality and Sustainability: Rethinking Islamic Mysticism through Contemporary Sociology. Comparative Islamic Studies, 4, 1-15.

Andrews, M. (2007). Shaping History. Cambridge, UK: Cambridge University Press. https://doi.org/10.1017/CBO9780511557859

Asmal, A. C., \& Asmal, M. (2000). As Islamic Perspective. In A. Chapman, R. Peterson, \& B. Smith-Moran (Eds.), Consumption, Population, and Sustainability: Perspectives from Science and Religion (pp. 157-165). Washington, DC: Island Press.

Bakhtin, M. (1981). The Dialogic Imagination. Austin, TX: University of Texas Press.

Barber, B. (1995). Jihad versus McWorld. New York: Ballantine.

Bube, P. C. (1988). Ethics in John Cobb's Process Theology. Atlanta, GA: Scholars Press.

Burckhardt, T. (2006). Sufi Doctrine and Method. In J.-L. Michon, \& R. Gaetani (Eds.), Sufism: Love Published by SCHOLINK INC. 
and Wisdom. Bloomington: World Wisdom.

Burns, T. J. (1999). Rhetoric as a Framework for Analyzing Cultural Constraint and Change. Current Perspectives in Social Theory, 19, 165-185.

Burns, T. J. (2009). Culture and the Natural Environment. In A. Begossi, \& P. F. Lopes (Eds.), Current Trends in Human Ecology (pp. 56-72). Newcastle upon Tyne, UK: Cambridge Scholars Press. https://doi.org/10.5848/CSP.0441.00003

Burns, T. J. (2014). Reconsidering Scripture in Late Industrial Society: Religious Traditions and the Natural Environment. In B. S. Caniglia, T. J. Burns, R. Gurney, \& E. L. Bond (Eds.), Rise of Environmental Consciousness: Voices in Pursuit of a Sustainable Planet (pp. 43-60). San Diego: Cognella Academic Publishing.

Burns, T. J. (2016). Toward a Theory of Culturally Maladaptive Beliefs: The Persistence of Anti-Environmentalism in the Anthropocene Age. Paper presented at conference of the International Consortium on Social Theory, Ames, Iowa.

Burns, T. J. (Ed., 2012). Canonical Texts: Selections from Religious Wisdom Traditions. San Diego: Cognella Academic Publishing.

Burns, T. J., \& Caniglia, B. S. (2017). Environmental Sociology: The Ecology of Late Modernity (2nd ed). Norman, OK \& Breckenridge, CO: Mercury Academic.

Burns, T. J., \& LeMoyne, T. (2001). How Environmental Movements Can Be More Effective: Prioritizing Environmental Themes in Political Discourse. Human Ecology Review, 8(1), 26-38.

Burns, T. J., \& LeMoyne, T. (2003). Epistemology, Culture and Rhetoric: Some Social Implications of Human Cognition. Current Perspectives in Social Theory, 22, 71-97. https://doi.org/10.1016/S0278-1204(03)80006-3

Burns, T. J., \& Rudel, T. K. (2015). Metatheorizing Structural Human Ecology at the Dawn of the Third Millennium. Human Ecology Review, 22(1), 13-33.

Chishti, S. (2007). Fitra: An Islamic Model for Humans and The Environment. In R. C. Foltz, F. M. Denny, \& A. H. Baharuddin (Eds.), Islam and Ecology: A Bestowed Trust (pp. 67-85). Cambridge: International Society for Science and Religion.

Chitlick, W. C. (1986). God Surrounds All Things: An Islamic Perspective on the Environment. The World and I, 1(6), 671-678.

Chitlick, W. C. (2000). Sufism: A Short Introduction. Oxford, UK: OneWorld Publications.

Clarke, L. (2009). The Universe Alive: Nature in the Masnavi of Jalal al-Din Rumi. In Foltz, R. C., F. M. Denny, \& A. H. Baharuddin (Eds.), Islam and Ecology: A Bestowed Trust (pp. 39-66). Cambridge: International Society for Science and Religion.

Cobb, J. B. (1995). Is It Too Late? The Theology of Ecology. Denton, TX: Environmental Ethics Books. Cobb, J. B. (1999). The Earthist Challenge to Economism: A Theological Critique of the World Bank. New York: St. Martin’s Press.

Cragg, K. (1971). The Mind of the Qurān: Chapters in Reflection. London: Allen and Unwin.

Published by SCHOLINK INC. 
Crutzen, P. J. (2002). Geology of Mankind: The Anthropocene. Nature, 415, 23. https://doi.org/10.1038/415023a

Daly, H. E., \& Cobb, J. B. (1994). For the Common Good: Redirecting the Economy toward Community, the Environment, and a Sustainable Future (updated and expanded, 2e). Boston: Beacon.

Dyson, T. (2010). Population and Development: The Demographic Transition. London: Zed Books.

Eisenberg, E. (1998). The Ecology of Eden: An Inquiry into the Dream of Paradise and a New Vision of Our Role in Nature. New York: Vintage.

Eissa, M. (2007). Al-Qushayris Epistle on Sufism: Al-Risala Al-Qushayriyya fi ilm Al-Tasawwuf. Reading: Garnet Publ.

Erdur, O. (1997). Reappropriating the “Green”: Islamist Environmentalism. New Perspectives on Turkey, 17, 151-166. https://doi.org/10.1017/S089663460000279X

Foster, J. B., Clark, B., \& York, R. (2011). The Ecological Rift: Capitalism's War on the Earth. New York: Monthly Review Press.

Fowler, R. B. (1995). The Greening of Protestant Thought. Chapel Hill, NC: University of North Carolina Press.

Fox, M. (1988). The Coming of the Cosmic Christ: The Healing of Mother Earth and the Birth of a Global Renaissance. San Francisco: Harper and Row.

Gadamer, H. -G. (1976). Philosophical Hermeneutics. Berkeley: University of California Press.

Gari, L. (2006). A history of the Hima Conservation System. Environment and History, 12(2), 213-228. https://doi.org/10.3197/096734006776680236

Geoffroy, É. (2006). Approaching Sufism. In J.-L. Michon, \& R. Gaetani (Eds), Sufism: Love and Wisdom (pp. 49-62). Bloomington, IN: World Wisdom.

Haq, S. N. (2001). Islam and Ecology: Toward Tetrieval and Reconstruction. Daedalus, 130(4), 141-177.

Hareuveni, N. (1991). Desert and Shepherd in Our Biblical Heritage. Kiryat Ono, Israel: Neot Kedumin.

Harrison, P. (1993). Inside the Third World: The Anatomy of Poverty. London: Penguin.

Idris, J. (1990). Is Man the Viceregent of God? Journal of Islamic Studies, 1, 99-110. https://doi.org/10.1093/jis/1.1.99

Inglehart, R. \& Baker, W. E. (2000). Modernization, Cultural Change, and the Persistence of Traditional Values. American Sociological Review, 65, 19-51. https://doi.org/10.2307/2657288

Jenkins, P. (2011). The Next Christendom (3rd ed). New York: Oxford University Press.

Jobling, D. (1977). “And Have Dominion...”: The Interpretation of Genesis 1: 28 in Philo Judaeus. Journal of the Study of Judaism, 8(1), 50-82. https://doi.org/10.1163/157006377X00031

Johnston, D. L. (2010). Earth, Empire and Sacred Text: Muslims and Christians as Trustees of Creation. London: Equinox.

Khalid, F. (1996). Guardians of The Natural Order. Our Planet, 8, 14-15. 
Kula, E. (2001). Islam and Environmental Conservation. Environmental Conservation, 28(1), 1-9. https://doi.org/10.1017/S0376892901000017

Lakoff, G., \& Johnson, M. (1980). Metaphors We Live By. Chicago: Univesity of Chicago Press.

McNeill, J. R. (2000). Something New under the Sun: An Environemental History of theTwentieth Century World. New York: W. W. Norton.

Michon, J. -L. \& Gaetani, R. (2006). Sufism: Love and Wisdom. Bloomington: World Wisdom.

Moore, J. W. (2000). Environmental Crisis and the Metabolic Rift in World-Historical Perspective. Organization and Environment, 13, 123-157. https://doi.org/10.1177/1086026600132001

Nasr, S. H. (1997). Man and Nature: The Spiritual Crisis of Modern Man. Chicago: ABC International Group.

Nasr, S. H. (2009). Islam, The Contemporary Islamic World, and The Environmental Crisis. In D. Clowney, \& P. Mosto (Eds), Earthcare: An Anthology in Environmental Ethics (pp. 82-90). Lanham, MD: Rowman and Littlefield Publishers.

Ogburn, W. (1932/1961). The Hypothesis of Cultural Lag. In T. Parsons, E. Shils, K. D. Naegele, \& J. R. Pitts (Eds), Theories of Society: Foundations of Modern Sociological Theory. New York: Free Press.

Ponting, C. (2008). A New Green History of the World: The Environment and the Collapse of Great Civilizations (2nd ed). New York: Penguin.

Renard, J. (2009). The A to Z of Sufism. Lanham, MD: The Scarecrow Press.

Rice, G. (1999). Islamic Ethics and The Implications For Business. Journal of Business Ethics, 18(4), 345-358. https://doi.org/10.1023/A:1005711414306

Rice, G. (2006). Pro-environmental Behavior In Egypt: Is There A Role For Islamic Environmental Ethics? Journal of Business Ethics, 65(4), 373-390. https://doi.org/10.1007/s10551-006-0010-9

Ricoeur, P. (1976). Interpretive Theory: Discourse and the Surplus of Meaning. Fort Worth, TX: TCU Press.

Ricoeur, P., \& Blaney, K. (1990). Time and Narrative. Chicago: University of Chicago Press.

Rizk, R. (2014). Islamic Environmental Ethics. Journal of Islamic Accounting and Business Research, 5(2), 194-204. https://doi.org/10.1108/JIABR-09-2012-0060

Royal, R. (1999). The Virgin and the Dynamo: The Use and Abuse of Religion in the Environmental Debate. Grand Rapids, MI: Eerdmans.

Saniotis, A. (2012). Muslims and Ecology: Fostering Islamic Environmental Ethics. Contemporary Islam, 6(2), 155-171. https://doi.org/10.1007/s11562-011-0173-8

Schnaiberg, A., \& Gould, K. A. (2000). Environment and Society: The Enduring Conflict. Caldwell, NJ: Blackburn Press.

Turner, A. (2017). All the Qur'an in 100 pages, by a non-Muslim for non-Muslims. London: Champagne Cat. 
Weber, M. (1903-1917/1949). The Methodology of the Social Sciences (E. Shils, \& H. Finch (Eds.)). New York: Free Press.

Weber, M. (1904-5/2002). The Protestant Ethic and the Spirit of Capitalism. London: Penguin.

Wersal, L. (1995). Islam and Environmental Ethics: Tradition Responds to Contemporary Challenges. Zygon, 30(3), 451-459. https://doi.org/10.1111/j.1467-9744.1995.tb00083.x

White, L. (March 10, 1967). The Historical Roots of Our Ecological Crisis. Science, 155(3767), 1203-1207. https://doi.org/10.1126/science.155.3767.1203

Wilkinson, J. C. (1990). Muslim Land and Water Law. Journal of Islamic Studies, 1(1), 154-172. https://doi.org/10.1093/jis/1.1.54

Williams, M. (2005). The Third World and Global Environmental Negotiations: Interests, Institutions and Ideas. Global Environmental Politics, 5(8), 48-69. https://doi.org/10.1162/1526380054794826 